2003

\title{
Enron - When All Systems Fail: Creative Destruction or Roadmap to Corporate Governance Reform
}

Douglas M. Branson

Follow this and additional works at: https://digitalcommons.law.villanova.edu/vlr

Part of the Business Organizations Law Commons

\section{Recommended Citation}

Douglas M. Branson, Enron - When All Systems Fail: Creative Destruction or Roadmap to Corporate Governance Reform, 48 Vill. L. Rev. 989 (2003).

Available at: https://digitalcommons.law.villanova.edu/vlr/vol48/iss4/1

This Symposia is brought to you for free and open access by Villanova University Charles Widger School of Law Digital Repository. It has been accepted for inclusion in Villanova Law Review by an authorized editor of Villanova University Charles Widger School of Law Digital Repository. 


\title{
VILLANOVA LAW REVIEW
}

VOLUME 48

NuMBER 4

\section{Articles}

\section{ENRON-WHEN ALL SYSTEMS FAIL: CREATIVE DESTRUCTION OR ROADMAP TO CORPORATE GOVERNANCE REFORM?}

\author{
DOUglas M. Branson*
}

\section{INTRODUCTION}

$\mathrm{E}$ NRON'S self-destruction has led to much in the way of corporate governance reform. The Sarbanes-Oxley $\mathrm{Act}^{1}$ is a package of fifteen or more "reform" measures, several of which hold promise for improvements in our governance scheme and several of which do not. ${ }^{2}$ But those hopes for improvement come with a cost. The reforms federalize controls over corporate officers and directors that traditionally have been the province of state law. ${ }^{3}$ They achieve, by the back door so to speak, what Ralph Nader and his cohorts failed to achieve in the $1970 \mathrm{~s}$-federal control of corporate behavior. ${ }^{4}$ Besides the great damage to federalism, SarbanesOxley's provisions, and the political climate surrounding them, may stifle

* W. Edward Sell Chair in Law, University of Pittsburgh.

1. See Sarbanes-Oxley Act of 2002, Pub. L. No. 107-204, 116 Stat. 745 (2002).

2. See Signing Statement of George W. Bush, July 30, 2002, available at http:// www.whitehouse.gov/news/releases/2002/07/20020730-10.html (suggesting that Sarbanes-Oxley contained most far-reaching reforms of American business practices since time of Franklin Delano Roosevelt).

3. See Douglas M. Branson, Corporate Governance v (1993) (“[G]iven that in the United States corporations are creatures of state and not federal laws, and given the so-called 'internal affairs' choice of law rule, that the law of the incorporating state controls issues of corporate governance, state law is the heart and soul of United States corporation law."); see also CTS Corp. v. Dynamics Corp. of Am., 481 U.S. 69, 78-87 (1987) (recognizing interplay between federal and state laws that regulate corporate governance); Richard M. Buxbaum, The Threatened Constitutionalization of the Internal Affairs Doctrine in Corporate Law, 75 CAL. L. REv. 29, 29 (1987) (acknowledging state government's interest in regulating corporate processes and federal government's efforts to control state regulations).

4. See, e.g., Ralph Nader, Mark Green \& Joel Seligman, Constitutionalizing the Corporation: The Case for Federal Chartering of Giant CorporaTIONS 1-85 (1976) (discussing federal role in corporate enterprise and development of federal chartering); Donald Schwartz, Federal Chartering of Corporations: An Introduction, 61 GEO. L.J. 71, $71-73$ (1972); Note, Federal Chartering of Corporations: A Proposal, 61 Geo. L.J. 89, 95-102 (1972); cf. William L. Cary, Federalism and Corporate Law: Reflections upon Delaware, 83 YALE L.J. 663, 700-03 (1974) (proposal 
the informed risk-taking that led to a decade of economic growth unparalleled in United States history, a decade in which our system of corporate governance arguably did improve and did work tolerably well.

Enron may just have been an aberration. Like an improbable airline crash, in Enron, error compounded error. Redundant systems failed. The auditors did not gain a full understanding of what had happened. Neither the Enron audit nor finance committees "caught it." The full board of directors did not "catch it." A prestigious law firm or two missed it. Neither the Securities Exchange Commission (SEC), the debt rating agencies nor the banks caught on.

If you believe former Enron CEO Jeffrey Skilling's and former Chairman Kenneth Lay's versions of events, they, too, did not fully realize what was occurring. Enron may have been a massive corporate governance failure that will be a rare occurrence in this era of good governance. ${ }^{5}$ If you factor in the other corporate governance imbroglios (Xerox, Quest Communications, ImClone, World Com, Global Crossing, Adelphia, Merck, Tyco and the like) into our year of corporate governance discontent, it still adds up to only approximately twenty companies out of the 16,200 companies that file periodic reports with the SEC. ${ }^{6}$

Arguably, any reform called for a rifle, not a shotgun, but what we received with Sarbanes-Oxley is something in between. In Part II of this Article, I attempt to articulate an overarching view of corporate governance as it has evolved, and vastly improved, since around 1980. In Part III, the story shifts to Enron and considers the improbability of such a complete implosion. Implosion raises the question of whether or not Enron, as the putative virtual firm, simply pushed the envelope too far, too soon, thus showing the way to the future for others who follow and, in that way, constituting "creative destruction."

Part VI scrolls through the Sarbanes-Oxley corporate governance reforms, reaching the conclusion many others have reached-that there are a few positives, not too many negatives and a host of open questions in the legislation. Part $\mathrm{V}$ delves into the real shortcoming of Sarbanes-Oxley, which is that it, and its authors and sponsors, failed to look completely at what is good about our system of corporate governance, with a view toward enabling and enhancing it. A sidebar is that the Congressional actors did nothing whatsoever about several glitches in governance that Congressional reports demonstrate led directly to Enron.

for federal minimum fiduciary and other standards, enforceable in court proceedings, rather than federal takeover of corporate chartering of large corporations).

5. This sentence and the previous paragraph paraphrase a solicited op-ed piece written for USA Today. See Douglas M. Branson, Enron Is an Aberration, USA Today, Mar. 1, 2002, at 9A.

6. See Framework for Enhancing the Quality of Financial Information Through Improvement of Oversight of the Auditing Process, 67 Fed. Reg. 44,964, 44,999 (proposed July 5,2002 ) (listing approximately 16,200 operating and 5000 investment companies reporting to SEC). 
By way of conclusion, Part VI returns to the creative destruction theme, not in the sense of destruction of a business plan that pushed the envelope too far, but in a broader, cultural sense. Enron, our other governance imbroglios, the political and market reactions thereto and all the other fallouts have led to creative destruction of the "winner's culture," "the good deal exemption" culture and the "rising tide floats all boats" (and covers up mistakes and opportunism) culture, which, in moderation, may or may not have served us well. Later in the 1990s, and into the new century, however, that culture constituted the real cancer in our system of corporate governance. The new ethics and the new culture that emerges from this troubled epoch may well be the real reform.

\section{The "Good Governance" Movement and Corporate GovernanCE 1980-2000}

\section{A. What is Corporate Governance?}

I have defined corporate governance as the process by which the power to allocate the corporation's resources, and the resources themselves, are allocated among the various organs of the corporation, namely, officers, directors, shareholders and employees. ${ }^{7}$

More eloquent is Professor John Farrar:

The etymology of "governance" comes from the Latin words gubermare and gubernator, which refer to steering a ship and to the steerer or captain of a ship. ... The word "governance," which has a rather archaic ring to it, comes from the old French word "gouvernance," and means control and the state of being governed.... Thus we have from the etymology of the word a useful metaphor-the idea of steering or captaining a ship. We have references to control and also to good order, which is more than simply being on course: it is also being shipshape and in good condition. ${ }^{8}$

\section{B. Governance in the Days of Ozzie and Harriet}

For most of the twentieth century, large corporations had self-perpetuating, insider-dominated boards of directors. The corporate president (today's CEO) handpicked candidates for board service. Routinely, a critical mass of directors including, for example, the executive vice-president (today's Chief Operating Officer), the corporate treasurer, a principal shareholder and the chief operating officers of two or three principal divisions or subsidiaries, or even a majority of directors, were insiders. Those

7. See, e.g., Branson, supra note $3, \$ 5.01$; see also Douglas M. Branson, Problems in Corporate Governance $17-27$ (1997). (2001).

8. John Farrar, Corporate Governance in Australia and New Zealand 3 
insiders were joined by outside directors who had a degree of financial dependency on the corporation, thus lacking independence. Among the latter might be an investment banker, a commercial banker or the senior partner from the headquarters' city law firm that did the bulk of the corporation's legal work. ${ }^{9}$

Refinements on this theme included neutralizing the board through large board size. For example, at one time, General Motors had a board of twenty-seven directors. ${ }^{10}$ On the very large boards, motivated directors who wished to be proactive faced collective action problems that prevented effective networking among fellow directors. The insider group, though less than majority, would almost always be assured of the ability to call the shots.

Another variant was the strong executive committee of the board. Often, the executive committee, which possessed nearly all the power of the full board, was the only board committee. The executive committee would not only be staffed predominantly, but rather exclusively, by insiders. Full board of directors meetings were window dressing. The real action took place within the executive committee.

In the days of Ozzie and Harriet, contrary to what one might expect, directors were not frustrated by the status quo. Outside directors enjoyed the prestige of office and financial perks, including a satisfactory annual retainer and meeting fees. Once a year, they would attend a "fly away" directors meeting or retreat at a resort or in New York or San Francisco. If they did disagree with management, the prevailing ethic of "love it or leave it" caused them to resign. Not many did so because being a director of a large United States corporation remained true to Lord Boothby's dictum in mid-Victorian England that being a company director is akin to a nice warm bath. ${ }^{11}$

Outside monitors of corporate performance were few. They might have included shareholders who were members of the business's founding families and who had retained large shareholdings, "relational investors" in today's terms. They included the outside "Big 8" accounting firm, which served as the independent auditor. Lastly, they included a lawyer or two, namely, the senior partner from the outside law firm and perhaps the senior "in house" lawyer.

Auditing firms performed only audit services. Although their independence might be comprised because of the substantial fees they would receive from the very entity whose financial statements they were auditing,

9. See Ralph D. Ward, 21 st Century Corporate Board 4 (1997).

10. See id. at 4. "Corporate boards, up until fairly recent times, were a disquieting example: the classic walnut-paneled boardroom, the strict rules on what was and was not to be said, the legalistic, ornate terminology, even the occasional member nodding off. Board meetings [resembled] . . one of those baroque rituals of British royalty that has long lost its original purpose." Id. at 198.

11. See Farrar, supra note 8, at 122. See generally Robert Rhodes James, Robert Boothby-A Portrait of Churchill's Ally (1991). 
they were not about to sacrifice their firm's reputation, which brought in many clients, for the sake of one or two renegade clients that wanted to push the envelope. Moreover, accounting firm partners were professionals who valued their reputation above all else. They exalted the principle of "accounting conservatism." They would never sign off on dubious or dishonest accounting tricks. ${ }^{12}$ They ensured that financial statements accurately represented economic reality.

In the 1970 s, the regulators took several steps to enhance auditor independence. The SEC made a change of auditors a reporting requirement for purposes of SEC Form $8 \mathrm{~K}$, which must be filed shortly after the change occurs and commands the attention of the SEC, if not the financial world. ${ }^{13}$ The Commission brought some celebrated cases against auditors, such as United States $v$. Carl J. Simon, ${ }^{14}$ that made clear what the Commission thought auditors' roles were.

Lawyers had clout. Corporations sent most of their legal work to one outside law firm. The senior partner through which business was funneled had as good an overview of the corporation's myriad of activities as anyone, save the president and the executive vice president. He (there were few "she's" in those days) sat on the board. Often he was a close confidant of the CEO. He filled the role not only of the attorney but of the "wise counselor" as well.

Those were idyllic days. Companies concentrated on producing goods and services and controlling costs. Revenues showed steady, but unspectacular growth. In 1955, the Dow Jones average stood at 442.72 and by 1960 , it had risen only to $618.04 .{ }^{15}$ Hostile takeover bids, New York arbitragers and poison pill takeover defenses were unknown. Finance and "financial guys" were not ends in themselves. They served only to provide funding for expansion or modernization, or to tide the company over during periods of reduced cash flow.

\section{Beginning Reform}

No particular spate of corporate scandals precipitated corporate governance reform in the United States. The fallout from the Vietnam War, the environmental movement, Earth Day in 1970 and the consumer movement were ciphers for a general angst that led to prolonged efforts to

12. Cf. Abraham Briloff, "We Often Paint Fakes”, 28 VAND. L. Rev. 165, 195-200 (1975) (providing "A to $\mathrm{Y}$ Roll of Dishonor," including lists of corporate names and corporations in which financial accounting was deficient).

13. See Regulation of Securities Offerings, 63 Fed. Reg. 67,174, 67,244 (proposed Dec. 4, 1998).

14. 425 F.2d 796, 806-08 (2d Cir. 1969) (noting that compliance with Generally Accepted Accounting Principles (GAAP) may be "very persuasive," but is not necessarily conclusive in accountant's defense under federal securities laws).

15. See Harbert Stein \& Murray Foss, The Illustrated Guide to the AmeriCAN ECONOMY 167 (3d ed. 1999) (table). In contrast, by 1996, the Dow stood at 5742.89. See id. In 1999, the Dow reached 10,700. See id. 
challenge and then change "the system." Large corporations were part and parcel of "the system." The corporate social responsibility movement of the mid-1970s called for corporate social accounting and disclosure, public interest corporate directors and increased consumer and worker protection. ${ }^{16}$ More broadly based were proposals for federal chartering of large corporations or for minimum federal standards that would displace overly lax state laws. ${ }^{17}$

Authoritative reform got underway in the late 1970s, again though, and unlike today, without the impetus of any particular corporate scandals. Corporate law had long provided that "the business and affairs of a company [be] managed by the board of directors." 18 In 1975, the American Bar Association Committee on Corporate Laws amended the Model Business Corporation Act, the law of thirty-six states, ${ }^{19}$ to accord with reality: "the business and affairs of [a] corporation [were to be] managed under the direction of [a] board of directors." 20 Especially in larger corporations, it had become a fiction that boards and directors actually did or could manage.

Another authoritative source came even closer to the reality of modern corporate life: the corporation's business and affairs were to be managed by the corporation's senior executives. In turn, rather than managing, the directors' role was to hire, to monitor and, if necessary, to replace the senior executive officers. ${ }^{21}$

In its monitoring role, the board of directors was to be assisted by a committee structure. The audit committee would help to assure the integrity of the accounting information upon which the full board would base its evaluations of senior executives. The audit committee became a sec-

16. See generally Douglas M. Branson, Corporate Governance "Reform" and the Ner" Corporate Social Responsibility, 62 U. PITT. L. Rev. 605, 611-615 (2001).

17. For a discussion on proposals for federal chartering, see supra note 3 and accompanying text.

18. See, e.g., Harry G. Henn, Law of Corporations $§ 203$, at 406 (2d ed. 1970) (board "shall manage business and affairs"); see also WILLIAM CLARK, JR., HaNDBoOK ON THE LaW OF CoRporations $\$ 192$, at 472 (2d ed. 1907) (same).

19. See Douglas M. Branson, Recent Changes to the Model Business Corporation Act: Death Knells for Main Street Corporation Law, 72 NeB. L. Rev. 258, 259-60 (1993) (listing states in which Model Business Corporations Act (MBCA) is effective).

20. See Committee on Corporate Laws, Changes in the Model Business Corporation Act, 29 Bus. LAw. 947, 949-56 (1974) (providing proposed revisions to MBCA $\S 35$ and comments to suggested amendments); Report of Committee on Corporate Laws: Changes in the Model Business Corporation Act, 30 Bus. LAw. 501, 501-03 (1975) (providing approval for revisions to MBCA $\S 35$ ).

21. See American Law Institute, Principles of Corporate Governance: ANALYSIS AND RECOMMENDATIONS $\$ 3.02$ (1994) ("The management of the business of a publicly held corporation should be conducted by or under the supervision of such principal senior executives as are designated by the board of directors ...."). "The board of directors of a publicly held corporation should ... [s] elect, regularly evaluate, fix the compensation of, and, where appropriate, replace the senior executives." Id. $\$ 3.02(\mathrm{a})(1)$. 
ond monitor, or a monitor within a monitor; as it pursued its specialist function on behalf of the full board of directors.

The nomination or governance committee would take the choice of board nominees out of the CEO's hands, thus preserving the independence of the board, which, in the $1980 \mathrm{~s}$, came to be populated with a majority or, indeed at many corporations, a super majority of independent directors. Through its repeated invocation of the business judgment rule, the Supreme Court of Delaware reinforced these developments. Each Delaware court opinion began with an inventory of directors, sorting them out as independent or not independent. In Delaware, decisions by truly independent directors were entitled not only to business judgment rule protection but to "heightened business judgment rule protection."22

\section{The "Good Governance" Era}

In the 1990 s, activist institutional investors, mainly public employee and labor union pension trusts, pushed hard for good governance at portfolio companies. Their agenda included a super majority of independent directors, bifurcation of the office of chairman and CEO, so that the CEO could no longer control the timing and agenda for meetings, secret balloting at shareholders' meetings, rescission of poison pill takeover defenses that entrenched management and declassification of staggered boards, which also represented an obstacle to takeovers and so on. Institutions became "relational investors" who focused not upon particular company specific issues but upon good governance. They became monitors of good governance in their activist role and monitors of firm performance in their investment role.

Large, mature companies often went to debt and commercial paper markets to borrow large sums. The debt rating agencies, such as Moody's, Fitch and Standard \& Poors, began tracking companies on a more or less continuous basis. A downgrade or placement on a credit watch list could impose hundreds of millions of additional borrowing costs on companies.

The "Big 8" shrunk to the "Big 5" through mergers. The SEC insisted upon a "clean" opinion letter accompanying financial statements. Wall Street insisted that the opinion letter be by a "Big 5" firm. Seemingly, accountants' and "Big 5" firms' hands were strengthened. The stock market boomed. Major securities firms hired analysts by the hundreds. Shirtsleeve capitalism spread like never before. Thousands of analysts monitored firm performance.

One monitor, or potential monitor of firm performance, faded in this era. Often the major headquarters' city law firm no longer captured and controlled a corporation's business. Corporations came to regard legal services as commodities to be purchased. The wise counselor role faded. Corporations spread their legal business among ten, twelve or even twenty

22. Ivanhoe P'ship v. Newmont Mining Co., 535 A.2d 1334, 1343 (Del. 1987). 
law firms, in part because they no longer wished to have any one outside lawyer who had an overview of the corporation's business dealings. Attorneys became transaction engineers dealing with a single "deal," or, if they performed well and priced their services right, a series of deals. Other law firms became litigation counsel, but only for a single piece of litigation, or a group of similar cases.

\section{E. A Preliminary Assessment}

Governance has come a long way from the Ozzie and Harriet days in which mushroom directors (kept in the dark with manure piled upon them) prevailed. Corporate performance, senior executives' performance and governance is closely watched by no less than eight or nine sets of monitors, including the independent directors who populate boards today; the audit committee; debt rating agencies; securities firms and their analysts; accounting firms who perform essential audit services; law firms in some cases; specialized regulators with whom reports are filed (state insurance commissions, Comptroller of the Currency, other banking authorities and Federal Energy Regulatory Commission (FERC)); the SEC, with whom companies file quarterly, annual and special reports; activist institutional and other relational investors; and the ever expanding financial press, ranging from CNN Financial to the Wall Street Journal, Fortune, Forbes and Business Week, to name a few.

Some of these monitors are "gatekeepers." Professor Jack Coffee defines gatekeepers as "reputational intermediaries who provide verification and certification services to investors." ${ }^{23}$ I would describe gatekeepers as a subset of monitors who supply essential verification and certification services to corporations. Legally, or practically, corporations cannot survive without the imprimatur of certain professionals and regulatory bodies. In turn, as third party beneficiaries of sorts, investors benefit, but they benefit by the presence and vigilance of all the monitors, not merely the gatekeepers.

Essential in modern corporate life are the verifications performed by the audit committee, the independent auditors, the debt rating agencies and state and federal regulators, including the SEC. By contrast, corporations can, and do, prosper, without a significant following by securities analysts, without big name law firms (which have often been supplanted by several firms as corporations spread their business around) and without institutional or other relational investors. Having analysts and institutions interested in your corporation can be very nice, but it is not essential.

The year before its demise, Enron had become the seventh largest corporation in the United States, in terms of market capitalization. Year after year Enron sat atop Fortune's list of "most admired" companies. As such, Enron had a first-class set of gatekeepers and monitors, including

23. John C. Coffee, Jr., Understanding Enron: It's About the Gatekeepers, Stupid, 57 Bus. LAw. 1403, 1405 (2002). 
strong representation by all the monitoring groups, ranging from a prestigious board and audit committee (including Arthur Andersen as auditors, Vinson \& Elkins as general counsel and Kirkland \& Ellis as counsel to its off book special purpose entities), to a myriad of securities analysts following the stock, strong institutional shareholding and daily coverage by the financial press. Yet nobody caught on to what Enron and its executives were up to. Why? What explains this massive failure of both monitors and gatekeepers? What happened?

\section{The Creative Destruction Hypothesis}

\section{A. The First Story-From Pedestrian Utility to Wannabe Trading Giant ${ }^{24}$}

Enron's roots were in natural gas (Houston Natural Gas) and pipelines. In 1984, Enron obtained, as CEO, the services of Kenneth Lay, a Ph.D. in economics, who had a strong belief in markets. Lay fended off a hostile takeover bid by Coastal Corp., in part with defensive acquisitions of Florida Gas and Transwestern Pipeline. He then caused Enron to team up with InterNorth, an Omaha based pipeline company whose network fit hand-in-glove with Enron's. After the merger, the surviving corporation, InterNorth, was renamed Enron. Still later, Lay fended off an attempt by takeover-player, Irwin Jacobs, to put Enron "in play."

With deregulation of natural gas in the second Reagan administration, Enron was perfectly situated. It had a CEO and other senior executives who understood markets and who also understood the ins and outs of the 200,000 mile gas pipeline grid that crisscrossed the United States. ${ }^{25}$ Enron then hired a former McKinsey \& Co. consultant, Jeffrey Skilling, who came to the company with ideas fresh from the financial world and the idea for a "natural gas bank."

Natural gas was becoming more in demand because of its environmentally desirable characteristics. Gas burns cleanly, almost invisibly, and had become the fuel of choice for industrial users and electric power plants. Indeed, with the demise of nuclear power, natural gas completely captured the new power plant market. Deregulation allowed for national markets, no longer subject to public utility commissions on a state-by-state basis. With gas's popularity, deregulation and national markets, however, came chaos and seemingly perpetual upward-trending prices.

Both producers and consumers desired to arrange in advance the purchase of some gas at fixed prices for delivery in the "forward" market.

24. I am grateful to Professor William Bratton who, among journalists, academics and others, has the most complete understanding of what occurred at Enron that I have encountered. Professor Bratton presented a virtuoso exposition at Tulane University School of Law in April 2002. See generally William Bratton, Enron and the Dark Side of Shareholder Value, 76 TUL. L. REV. 1275 (2002).

25. The network is five times as long as the interstate highway system, which is 46,000 miles long. WORLD FACTBOOK (2002), available at /geos/us.html (listing length of U.S. expressway system as 45,936 miles, length of U.S. gas pipeline system as 205,220 miles). 
Other consumers did not want to be forced to purchase gas they did not need. They were interested in options to buy at stated prices, rather than firm "forward contracts." Under Skilling's tutelage, Enron began to trade and slice these contracts, much as New York financiers had taken to carving up traditional financial products such as debt, into separate rights to receive interest and principal, and so on. Enron also provided "swaps" that would allow a consumer to trade a fixed price contract for a floating price contract, or to trade an option for a forward contract.

Enron delivered some of the gas through its pipeline network but it could also arrange for local distributors in various parts of the country to deliver the gas. Enron's profits equaled the difference between the contract price and the price it had to pay the local gas distributor. As the middleman between producers and consumers, Enron was able to mark up prices in other ways as well.

Skilling and Enron learned, though, that they had only a two-year or so head start on would-be competitors. While the liquidity provided by the market made the commodity trading (for example, gas contracts) quite lucrative, the increased profits so engendered attracted competitors. Already, Williams Co. and El Paso Natural Gas Corp. had implemented business plans to become trading companies in natural gas and pipeline capacities.

So Kenneth Lay, Jeffrey Skilling and Enron took the trading model and applied it to other fields where they might not have had the expertise they had in natural gas, but in which their trading prowess would provide benefits. They began to expand into electric power, water, fiber optic networks bandwidth capacity, pulp and paper, specialty chemicals, metals, pollution credits and others, even eyeing the worldwide market in pollution credits that would result from implementation of the Kyoto Accords. At its peak, Enron traded in over 1800 markets. ${ }^{26}$

\section{B. The Second Story-Lumpy Markets}

Enron's design was to become the ultimate trading company, nearly a virtual firm. As such, it hired bright, high-energy young people. The only necessary hard assets were tables, chairs and computers. The trading business relied on brain power and bravado, and, seemingly, was not capital intensive. Enron moved trading activities to the Internet with Enron Online.

What Enron discovered, though, was that while it had purchasers, it did not have sellers. At other times, the reverse was true. The markets in many other areas were not as well developed as in natural gas. Imbalances between the buy and sell sides, if not an absence of traders, plagued what often turned out to be thin markets. To remedy this, sometimes to tide itself over until a time when markets became more liquid and also to earn

26. See Peter C. Fusaro \& Ross M. Miller, What Went Wrong at Enron: Everyone's Guide to the Largest Bankruptcy in U.S. History, $77-78$ (2002). 
markups rather than mere broker's commissions, Enron began to enter into trading transactions as the counterparty.

As a counterparty, Enron often had to obtain or maintain an inventory of product, or contractual rights to receive product. Suddenly, a business that had very light capital requirements became an extremely capital intensive one. To continue to push the envelope as a trading company, Enron needed cash and liquid assets. Fortunately, Enron had hard assets galore, ranging from its pipelines and gas companies to its water company (Azurix), to Portland General Electric, the electric utility in Oregon.

\section{The Third Story-The Asset-"Lite" Business Plan}

Enron began to relieve itself of hard assets. ${ }^{27}$ The corporation sold assets, and bits and pieces of assets sometimes at a loss, sometimes booking a profit on the sales. Enron also "sold" choses in action, such as shares of stock in subsidiaries it intended to spin off and take public, or even more contingent claims, such as options to acquire shares in those future ventures. The asset-"lite" strategy had at least three goals: (1) create liquidity so that Enron could act quickly to begin trading in new markets and be the counterparty; (2) free up cash to acquire other hard assets when that was necessary to enter a new market such a fiber optics and broadband; and (3) move debt off Enron's balance sheet to preserve the debt rating, which, while never high, Enron enjoyed, and which gave Enron credibility as a counterparty in trading transactions. "Without an investment-grade bond rating, Enron could no longer be a viable counterparty for new businesses-it could no longer be relied upon to deliver on its side of the contracts it wrote." 28

\section{The Fourth and Final Act-Fastow Special Purpose Entities and Shenanigans}

At some point, Enron found that it could not sell or otherwise move assets and related debt off its balance sheet quickly enough, or at all. It was then that the newly promoted Andrew Fastow began breaking the rules, in the process succumbing to the moral hazard and enriching himself by at least $\$ 45$ million.

Very briefly, Enron had a venture, Joint Energy Development Investments (JEDI, or JEDI I) with the California Public Employees Retirement System (CalPERS). Enron wanted to move CalPERS to a new venture, JEDI II. Enron could not, however, find an investor who would substitute for CalPERS in JEDI I. So Enron manufactured a purchaser of CalPERS's

27. See, e.g., Enron Corp., 2000 Annual Report, Management Discussion and Analysis, available at http:/ /www.enron.com/corp/investors/annuals/2000/about. html ("We are participating in a New Economy and the rules have changed dramatically. What you own is not as important as what you know. . . . It is our intellectual capital-not only our physical assets-that makes us Enron.").

28. Fusaro \& Miller, supra note 26, at 117. 
interest, a special purpose entity, which, continuing the Star Wars theme, Fastow and Enron named Chewco, after Chewbacca, the friendly hairy giant, who acted as Han Solo's co-pilot.

The rules for moving assets and related debts off books had become well developed in the area of practice known as "securitization." 29 For example, a bank that wanted to free up capital that was "sunk" into mortgages or credit card receivables could create a new special purpose entity (SPE), to which those assets would be sold. The SPE would offer securities (often with high yields reflecting the risk of uncollectability of some of the assets acquired) to the public through a private placement or other offering.

Before investing, however, the public would want assurance that, if the originator (the bank or other corporation) got into financial trouble, the assets in the SPE would be "bankruptcy remote," that is, out of the potential grasp of the originator's creditors. The assurance would be provided by the public's procurement (or really procurement by the investment banker doing the offering, long before the public was on the scene) of a "true sale" opinion by a reputable law firm.

The prerequisites for a true sale opinion were simple. The SPE had to have independent capital equivalent to three percent or more of the total transaction. If the originator were moving $\$ 1$ billion of rights to movie box office receipts or student loan receivables, for example, it would have to find independent investors willing to stake the new venture with $\$ 30$ million. Often, knowing that they would make far more on the "spread" in the subsequent offering, investment banking firms would advance the three percent.

The SPE also had to have an independent governance structure. So whether the SPE were a business trust, a limited liability company, a corporation or some other vehicle, the originator could not control the trustees, managing members, directors or other similar actors.

Fastow had difficulty finding a three percent "grubstake" or "seed capital" investor for Chewco. Finally, he was able to get Barclay's Bank to advance funds under an arrangement termed a "participation," which looked like equity of some kind, but was really a loan. After that, Fastow vowed, "never again." He then formed two partnerships named after his wife, Lea, and his two children, which he termed LJM1 and LJM2. These partnerships entered the private placement market, raising hundreds of

29. See, e.g., Michael J. Cohn, Asset Securitization: How Remote Is Bankruptcy Remote?, 26 Hofstra L. REv. 929, 929-80 (1998); Christopher W. Frost, Asset Securitization and Comporate Risk Allocation, 72 TuL. L. REv. 101, 101-02 (1997); Walter G. McNeill \& Daniel J. Mette, Accounting for Securitizations Under FAS 125: Why Lawyers Are Writing About It, 114 BANkING L.J. 716, 717-19 (1997). A "securitization" keyword search produced 172 citations to articles with securitization in the title. The Legal Trac Search dated January 3, 2003, is on file with the author. A postEnron literature is also developing. See generally, Kenneth N. Klee \& Brendt C. Butler, Asset-Backed Securitization, Special Purpose Vehicles and Other Securitization Issues, 35 UCC L.J. 23 (No. 2) (2002). 
millions of dollars on the promise of fantastic returns which, ultimately, they delivered.

In turn, the LJM partnerships became the supplier of "seed capital" to an array of SPEs Fastow created, which could take your breath away, nine hundred or so by one count. Fastow flouted all of the rules. In many of the SPEs, he, or one of his lieutenants, such as Michael Kopper, served as trustee or managing partner, raking in handsome management fees in the process. There was neither independent investment nor independent governance.

Fastow moved everything but the kitchen sink, including junk, into SPEs. One transfer that illustrates the phantasmagoric reality of what occurred on Fastow's watch at Enron involved NewPower Holdings. ${ }^{30}$ Enron had a subsidiary that Enron Energy Services (EES) spun off, NewPower Holdings. In its very best year, NewPower booked a $\$ 25$ million loss on $\$ 7.8$ million in revenues. ${ }^{31}$ In the spin off, EES contributed electric and natural gas contracts to NewPower. In return, it received 14.8 million shares and options to acquire 45 million NewPower shares at $\$ .05$ per share. Enron dropped these options, which were restricted and not immediately exercisable, down into a series of limited liability companies it formed, McGarret I, II, III and so on. The entertainment theme here was the television series, "Hawaii 5-0," and in fact one of the entities Fastow used was "Hawaii 125-0."

The McGarret entities then sold tranches of the options to a series of Delaware business trusts, Hawaii I, II, III and so on. The Hawaii trusts were able to obtain cash from banks-in this case the International Bank of Commerce in Canada-because Enron would pledge Enron shares to secure the loan, give guarantees to the lender or do whatever it took. In the process, the "independence" of the SPE became an even larger joke.

Enron, though, would do further violence to the independence of the SPEs. To work both sides of the street (or have its cake and eat it toochoose your metaphor) Enron would enter into "total return swaps" with the trusts so that Enron could enjoy any increase in value of the NewPower options. When NewPower successfully sold shares at $\$ 21$ per share, first in a private placement, and later in an initial public offering, Enron "marked to market" the swaps, which, in turn, were proxies for the options, which were proxies for shares themselves. In that way, Enron booked $\$ 52 \mathrm{mil}-$ lion in the McGarret A swap and $\$ 66$ million in the McGarret B swap. After the NewPower IPO on October 5, 2000, Enron booked an additional $\$ 184$ million in "vapor" revenue. ${ }^{32}$

The NewPower offering went off at $\$ 21$ per share. If the share price fell, as prices often do after a public offering, Enron would again have to

30. See generally In re Enron, No. 01-16034(AJG), at 22-34 (S.D.N.Y. Sept. 21, 2002) (First Interim Report of Neal Batson, Court-Appointed Examiner).

31. See id. at 25.

32. See id. at 30 . 
mark to market, recognizing losses on its total return swap. To lock in its gains of $\$ 246$ million in excess of related debt, Enron entered into hedge transactions regarding the NewPower "Hawaii" transactions. The hedge, however, was with another Enron off-books entity, Porcupine I, LLC. Enron traded the total return swaps in exchange for Porcupine's $\$ 259$ promissory note, entitling Porcupine to any further increase (not likely) in the NewPower shares.

The hedge, of course, was a sham. There was no shifting of the risk. Instead, Enron removed the risk of a decline in the NewPower shares from one pocket and placed it in another. By December 31, 2000, the NewPower shares had declined to $\$ 9.81$. Enron had to write down the value of the total return swaps by $\$ 200$. The hedge was as useless as Porcupine was insolvent. Nevertheless, Enron postponed the day of reckoning by "cross collaterization agreements" by and between Enron and the LJM2 partnership involving the assets of four Raptor SPEs. ${ }^{33}$

Just this bit of legerdemain with NewPower options allowed Enron to book $\$ 370$ million in income in 2000 , which was fifteen percent of Enron's total income before interest and taxes (IBIT). So even in 2000, the last "good" year for Enron, the emperor had no clothes.

\section{E. Creative Destruction?}

The first three Enron stories recounted here involve no wrongdoing. They demonstrate some of the difficulties inherent in the creation of a near virtual trading firm. They demonstrate once again the pitfalls in overly rapid expansion, an object lesson many entrepreneurial companies never seem to learn. They may also demonstrate evolution of a "win at all costs" culture that may be blameworthy in the moral but not in the legal sense. ${ }^{34}$

Only in story number four does real wrongdoing raise its ugly head. By and large, that wrongdoing seems confined to the CFO's office suite. Subsequent events confirm this. The first and only higher-up at Enron that the Justice Department is actively pursuing is Andrew Fastow, the Enron CFO who enriched himself with the SPEs he created. ${ }^{35}$ Looking back on it, Jeffrey Skilling's explanation of what brought Enron down, a "run

33. See id. at 34 .

34. See, e.g., Fusaro \& Miller, supra note 26, at 51-52 ("Enron has been described by many employees as having an absolutely cutthroat culture that pitted one employee against another" and "an environment where most employees were afraid to express their opinions or to question unethical and potentially illegal business practices.").

35. See Jonathan Weil, U.S. May Bring Criminal Charges Against Enron's Fastow Next Week, Wall St. J., Sept. 26, 2002, at A3. But see Rebecca Smith \& John Emshwiller, Prosecutors Probe Skilling's Role in Enron's Failed Telcom Venture, WaLL ST. J., Dec. 13, 2002, at A1 (reporting that Enron booked $\$ 110$ million profit in failed Braveheart video on demand venture with Blockbuster Video). 
on the bank," has more plausibility. ${ }^{36}$ As the value of Enron shares fell, the value of much of the assets pledged to secure many of the SPEs' obligations to third party lenders (Enron shares and other obligations) fell, leading to defaults, triggering yet further defaults.

Assessing Horatio Nelson "blind eye" fault at Enron is altogether another matter. ${ }^{37}$ Skilling seems disingenuous when in testimony he denies knowledge of the company's vast network of complex partnership to hide debt. ${ }^{38}$ His answer to nearly every question posed (badly) by Senators on the Commerce Committee was the same: "I am not an accountant."

By acceptance of outrageously high directors' fees and, in many cases, consulting contracts as well, the Enron board members compromised their independence. Whether they turned a blind eye to observable wrongdoing seems doubtful. They seemed to not ask the right questions, to have been too eager to waive the Enron code of conduct's conflict of interest provisions, so that Fastow could be managing partner of SPEs he created and to have failed in coordinating the work of their committees. Board members face several lifetimes' worth of civil litigation, but, evidently, the Justice Department has decided not to pursue any board members criminally.

All in all, beyond Andrew Fastow and his gunslinger mentality, it is difficult to assess blame. It is even more difficult to write prescriptions for discrete reforms that will raise the level of performance of all the myriad gatekeepers and monitors who play important roles in United States corporate governance.

\section{Enron and Sarbanes-Oxley-Roadmap to Meaningful Reform?}

This Part discusses what Congress did, without too much in the way of excursions into technical detail. I confine myself to corporate governance subjects, leaving for another day those Sarbanes-Oxley Act provisions that belong in the area of securities law.

\section{A. CEO and CFO Quarterly and Annual Section 302 Certifications of Financial Statements and Intemal Accounting Controls}

Under section 302 of the Act, the CEO and the CFO must certify that they have reviewed the report $(10 Q$ or $10 \mathrm{~K})$, that the report does not con-

36. See Financial Collapse of Enron-Part 2: Hearing Before the Subcomm. on Oversight and Investigators of the House Comm. on Energy and Commerce, 107th Cong. 91-93 (2002) (quoting testimony of Jeffrey Skilling: “[I]t is my belief that Enron's failure was due to a classic 'run on the bank'-a liquidity crisis spurred by a lack of confidence in the company. At the time of Enron's collapse, the company was solvent, and highly profitable, but, apparently not liquid enough.").

37. At the Battle of the Nile, the senior admiral ran up a signal "disengage" on the flagship's yardarm. As a vice admiral in charge of a column of ships, Horatio Nelson put his long glass to his blind eye, remarking "I see no signal." He then engaged the French fleet, carried the day and added to his legend.

38. See Fusaro \& Miller, supra note 26, at 26. 
tain any material misstatement or omission and that "the financial statements, and other financial information, fairly present in all material respects the financial condition and results of operation of the issuer." They must also certify that within the past ninety days, they have evaluated the issuer's internal controls and that they have presented their conclusions in the report. Finally they must certify ancillary facts supporting the ultimate facts certified.

Four points may be made about these provisions and the SEC rules that will implement them:

1. Overkill. These certifications and developing intracorporate processes leading up to them will require an expenditure of significant effort and be an event of great stress for many CEOs, CFOs and corporate headquarters' staffs. ${ }^{39}$ The new regulatory scheme will pressure and stress 998 honest and capable CEOs and CFOs in order to reveal the one or two rotten apples in the barrel (for example, the Rigas at Adelphia Communications, Inc.). The approach is a zero defects approach that is inefficient.

2. False Accuracy. This added certification of financial statements will lead the public to believe, more than ever, that financial accounting possesses a degree of accuracy it can never possess. The "expectations gap"the gap between what the public expects and what accountants can deliver-will widen. ${ }^{40}$ Many questions regarding choice of accounting principle, expensing versus capitalizing costs, revenue recognition and so on have subjective elements to them. The exact same facts may lead to differ-

39. SEC Adopts CEO, CFO Certification Rules for Periodic Reports, Fulfilling New Law, 34 Sec. Rec. \& L. Rep.(BNA) 1452 (Sept. 2, 2002). In reality, the CEO and CFO must make no less than nine individual determinations, certifying, as follows:

1. They have read the quarterly or annual report.

2. Based on their knowledge, the report does not contain any untrue statements of a material fact or fail to state a material fact.

3. The financial statements and the financial information contained therein fairly present in all material respects the financial condition and the results of operations of the company.

4. They are responsible for establishing and maintaining "disclosure controls and procedures."

5 . They have designed the disclosure controls and procedures to ensure that material information is made known to them.

6 . Within the previous ninety days, they have evaluated the effectiveness of the company's disclosure controls and procedures.

7. They have presented in the report their conclusions regarding controls and procedures.

8 . They have disclosed to the outside auditors and to the audit committee all significant deficiencies in the design or operation of internal accounting controls and procedures.

9 . They have indicated in the report whether or not there were any significant changes in internal accounting controls that could affect controls subsequent to their evaluation.

40. See Donald C. Langevoort, Managing the Expectations Gap in Investor Protection: The SEC and the Post-Enron Reform Agenda, 48 VILL. L. Rev. (forthcoming July 2003). Professor Langevoort expounds on this theme in his contribution to this symposium. See id. 
ing results depending upon who the accountants, CEOs, CFOs and other decision makers are.

3. Filling the Gaps in GAAP? In the United States, accountants audit financial statements prepared by the company. The accountants then render an opinion that "the financial statements ... present fairly, in all material respects, the financial position of [the company] . . in conformity with accounting principles generally accepted in the United States," or GAAP. ${ }^{41}$ In much of the rest of the English-speaking world, accountants step up to the plate, rendering an opinion that the financial statements "present a true and fair view" of the state of affairs within the company. ${ }^{42}$ Consistency with GAAP is secondary.

From time to time courts in the United States have gone further. If GAAP does not result in an accurate picture, then the accountant must go beyond GAAP to ensure that a fair and accurate picture was presented. From time to time the SEC has joined in this view. ${ }^{43}$

Sarbanes-Oxley may then bring the United States closer to a worldwide standard and make clear that the primary onus for a "true and fair view" rests with the corporation's senior executive officers.

4. Conscience Raising. The legislation will certainly bring to the forefront of $\mathrm{CEO}$ and CFO consciousness the importance of financial reporting and internal controls that aid in the production of reliable information.

\section{B. Annual Section 404 Certification}

In SEC Form 10K, the CEO and CFO must also make a different sort of certification. They must (1) state the responsibility of management for establishing and maintaining internal accounting controls; (2) assess the effectiveness of those controls; and (3) obtain and include an attestation by the outside auditors as to management's assessments. ${ }^{44}$ Although there seems to be some overlap with the section 302 certifications, and the legislation seems to have been put together in slap dash fashion, advisers are treating the two sets of certifications altogether separately and an argot has developed. In Sarbanes-Oxley speak, lawyers and accountants talk of 302 and 404 certifications.

41. Letter of Arthur Andersen, LLP, in Alaska Air Group, 2001 Annual RePORT 51 .

42. See, e.g., Corporations Act, 2001 (No. 50) $\$ \$ 295-299$ (Austl.).

43. See United States v. Simon, 425 F.2d 796, 805-06 (2d Cir. 1969) (indicating that "compliance with generally accepted standards was 'evidence which may be persuasive but not necessarily conclusive that he acted in good faith and that the facts as certified were not materially false or misleading'").

44. See Sarbanes-Oxley Act of 2002, Pub. L. No. 107-204, § 404, 116 Stat. 745, 789 (2002). 


\section{Audit Committee Requirements}

Audit committees, which all of the self-regulatory organizations (SROs) already require, now must be comprised exclusively of independent directors. ${ }^{45}$ Implementation is to be by SEC supervised amendment of the SRO's listing standards. At least one director on the committee must be a "financial expert." 46 As a matter of federal law, the audit committee now will be "directly responsible for the appointment, compensation and oversight of the work" of the outside auditor, and the auditing firm will report to the audit committee rather than the full board. ${ }^{47}$ The Act grants the audit committee authority as a matter of federal law to engage independent accountants and other consultants. ${ }^{48}$ Each year the auditors must make a formal report to the committee regarding critical policies and practices being used and communications between management and the auditors. ${ }^{49}$ In short, not management, and not the board of directors, but the audit committee has become the client of the outside auditing firm.

Federal law now also mandates that it is the audit committee which is to be the receptacle for anonymous submissions by corporate employees concerning "questionable accounting and auditing matters." 50

The latter provision does what good practice shuns, that is, putting upon audit committees responsibilities that may cause the committee to lose its focus. The provisions also do great violence to federalism. Boards and board committees including their appointment and composition, are matters of state corporate law.

Finally, another provision strengthens an audit committee's hand by requiring that the committee approve in advance all auditing and nonaudit services provided to the corporation by the outside auditing firm. ${ }^{51}$ The downside is that, yet again, legal requirements and best practices combine to make audit committee membership potentially a nearly full time job.

45. See id. $\$ 301$ (to be codified as Securities Exchange Act $\S 10 \mathrm{~A}(\mathrm{~m})$ ). Attorneys, bankers or consultants who receive fees directly or through their firms may continue to serve on the board but may not serve on the audit committee. See id. See id.

46. See id. $\S \S 401$ (a)-(b). The SEC has power by regulation to define "expert."

47. See id. $\S 301$ (to be codified as Securities Exchange Act $\S 10 \mathrm{~A}(\mathrm{~m})(2)$ ).

48. See id.; cf. Principles of Corporate Governance: Analysis and RecomMENDATIONS $\$ 3.04$ (1994) (outlining "Right of Directors Who Have No Significant Relationship with the Corporation's Senior Executives to Retain Outside Experts"). The section recommends empowering the independent directors "acting as a body by the vote of a majority of such directors [rather than the audit committee], to retain legal counsel, accountants, or other experts, at the corporation's expense." Id.

49. See Sarbanes-Oxley Act $\S 204$.

50. See id.

51. See id. $\S 202$ (to be codified as Securities Exchange Act $§ 10 \mathrm{~A}(\mathrm{i})$ ). 


\section{Expanded Penny Stock Reform Act Powers to Bar Service as Officer or Director}

The SEC chafed under the 1990 requirement that the agency go to federal district court. The Commission chafed further under the 1990 act that required the agency prove "substantial unfitness to serve." Last of all, the SEC felt burdened by the court's adoption of Professor Jayne Barnard's six factor test of "substantial unfitness to serve."52

Now the SEC can bar directors and officers in administrative proceedings. The SEC staff need only prove "unfitness to serve." 53

Essentially, this new power is federalization of the standards of conduct for directors. It constitutes the business equivalent of the "death penalty." 54 It is extremely scary "Big Brother" government in action.

\section{E. CEO and CFO Forfeiture of Incentive Based or Equity Based Compensation}

If the corporation restates financial results based upon prior "misconduct," the CEO and CFO forfeit compensation received in the prior twelve months, including profits from the sale of issuer stock during that period. ${ }^{55}$ Precisely what the misconduct must be, and whether by the higher-ups or merely by any subordinate, is unclear. What is clear is that in some cases the penalty will operate in draconian fashion. It may lead to further cover-ups rather than the prompt disclosure that is an overall objective of federal securities laws.

\section{F. Prohibition on Loans or Arranging Credit for Corporate Officers and Directors}

Under Sarbanes-Oxley section 402(a), corporations may continue to arrange home loans and certain types of consumer credit on "market terms ... no more favorable than those offered by the issuer to the general public."56 The provision aims to prevent the practice whereby corporations lent money or arranged for bank loans, so that corporate officials could exercise stock options, paying off the loans with the proceeds of the subsequent, and nearly simultaneous, sale of the shares.

52. See Jackie Spinner, Errant Directors May Face SEC Ban; Agency to Request New Authority, WAsh. Post, Feb. 16, 2002, at E1; see also Jayne W. Barnard, When Is a Corporate Executive "Substantially Unfit to Serve"?, 70 N.C. L. REv. 1489, 1492-93 (1992) (enunciating her six factor test). The test was adopted, inter alia, by the Second Circuit in SEC v. Patel, 61 F.3d 137, 141 (2d Cir. 1995) (delineating six factors considered in resolving issue of substantial unfitness).

53. See Sarbanes-Oxley Act $\$ 305$ (amending Securities Exchange Act $\$ 21(\mathrm{~d})(2))$.

54. See Spinner, supra note 51, at E1 (quoting Orlan Johnson, Esq., of Milbank, Tweed, Hadley \& McCloy).

55. See Sarbanes-Oxley Act $\$ 304$ (a) (to be codified as Securities Exchange Act $\S 10 \mathrm{~A}(\mathrm{~m})(2))$. $\S 13(\mathbf{k})$

56. Sarbanes-Oxley Act $\S 402(a)$ (amending Securities Exchange Act of 1934 
State law used to regulate the practice. The 1950 Model Business Corporation Act (MBCA) flatly prohibited loans to officers and directors. The 1969 MBCA permitted the practice, but only pursuant to a shareholder vote. Finally, MBCA Third, promulgated in 1984, abdicated any special control over loans to officers and directors. ${ }^{57}$

Section 402(a) is a reaction to Enron's loans to Chairman Kenneth Lay, which enabled him to exercise options and realize a $\$ 100$ million profit in the year of Enron's demise. Lay's revolving line of credit was known as his "Enron ATM." He also repaid his loans through the sale of shares back to the company, thereby avoiding monthly section 16(a) reports.

\section{G. Mandatory Codes of Ethics for Senior Financial Officers}

Sarbanes-Oxley further provides that corporations must disclose whether or not they have adopted a code of ethics for senior financial officers (which all but masochistic managements will do). ${ }^{58}$ Changes in or waivers of the code, as Enron's board twice did to facilitate Andrew Fastow's service as managing partner of SPEs and receipt of gargantuan fees therefore, are now reporting events for purposes of SEC Form $8 \mathrm{~K}$, which is now to be filed on a real time, or near real time, basis. The code must contain standards "reasonably necessary to promote honest and ethical conduct, including the ethical handling of actual or apparent conflicts of interest between personal and professional relationships" and promote "compliance with applicable governmental rules and regulations."59

Corporate codes of conduct have been around for approximately twenty years. Enron had a code. Codes can serve to raise the level of ethical behavior within an organization, but only if they are taken seriously and enforced. Here, though, Sarbanes-Oxley runs afoul of the age-old proscription against attempts to legislate morality. The law cannot and should not attempt to make itself coextensive with morality.

\section{H. Corporate Officer and Direct or Real Time Section 16 Reporting}

In this instance, "real time" means within two business days of a trade, rather than the current requirement of reporting only within ten days after the last day of a month in which a trade takes place. ${ }^{60}$ Further, companies must within three additional days post the trade information on the company's web site.

In Enron Chairman Kenneth Lay's case, the SEC's rules required reporting only at the end of the calendar year, as Lay sold shares back to the company rather than on the open market. The Act closes that loophole.

57. See generally Branson, supra note $3, \S 8.21$ (discussing MBCA Third's requirements regarding "Loans to Officers and Directors").

58. See Sarbanes-Oxley Act $\S \S 406(\mathrm{a})$-(b).

59. Id.

60. See Securities Exchange Act of 1934, 15 U.S.C. $§ 78 p$ (1997). 
Also, by the first anniversary of the Act's passage, section 16(a) reports must be filed electronically. ${ }^{61}$

Congress did not, however, correct what has become a real abuse: under section 16, the date of acquisition of shares acquired pursuant to stock options is the date the options were exercisable and not the date of actual exercise. That construction permits corporate officers and directors to engage in virtually risk-free transactions, exercising options and immediately selling shares without fear of section 16 liability.

Sarbanes-Oxley does introduce another form of section 16-like liability. Either the corporation or any shareholder may sue to recover profits made by any officer or director who trades company stock acquired by virtue of his or her employment during any "blackout period" when corporate employees are not able to trade in their $401(\mathrm{k})$ or similar individually directed retirement plans. ${ }^{62}$ As Enron crumbled, of course, employees had to endure an extended blackout period because of a change of plan administrators. At the same time, Enron higher-ups continued to sell shares.

\section{Auditor "Revolving Door" Prohibition and Audit Partner Rotation Requirement}

The last four Sarbanes-Oxley provisions this Article addresses involve monitors of companies rather than companies or directors and officers of companies. An accounting firm may not provide audit services to any company whose CEO, controller, CFO, chief accounting officer "or [other] person serving in an equivalent position" in the past year worked for the accounting firm. ${ }^{63}$ The Act thus may necessitate a one year wait before an accountant who served as lead or audit partner or as reviewing partner can pass through the revolving door leading into an audit client's executive suites.

The Act requires accounting firms to rotate the lead audit partner at least every five years. ${ }^{64}$ The Act stopped short of requiring mandatory periodic rotation of audit firms that some onlookers recommended.

\section{J. Auditor Registration and Separation of Consulting Services from Auditing}

Firms that wish to audit publicly held corporations must register with the new "Public Company Accounting Oversight Board" (the Board), which the Act creates. ${ }^{65}$ Registered firms must then submit annual and

61. See Sarbanes-Oxley Act $\$ 403$ (amending 15 U.S.C. $\$ 78 p$ ).

62. See Sarbanes-Oxley Act $\$ 306(a)(1)$ (amending of Employee Retirement Income Security Act (ERISA) of 1974) $\$ 101$.

63. See Sarbanes-Oxley Act $\$ 206$ (to be codified as of Securities Exchange Act) $\$ 10 \mathrm{~A}(1)$.

64. See Sarbanes-Oxley Act $\S 203$ (to be codified as of Securities Exchange Act) $\S 10 \mathrm{~A}(\mathrm{j})$.

65. See Sarbanes-Oxley Act $\S 102(a)$. 
other reports to the Board while at the same time paying annual fees, which, along with payments by issuers, will fund the Board. Board staff must undertake yearly inspections of any accounting firm that audits more than one hundred reporting companies (specifically, the "Big 4"). At least every three years, Board staff must inspect firms that audit less than one hundred public companies (basically those firms known as the "medium 18 ").

More importantly, the Act takes what the SEC was nearly requiring by regulation, enacting into positive law prohibitions on providing non-audit services (consulting) while also providing audit services. ${ }^{66}$ Enron paid $\$ 52$ million to Arthur Andersen in $2000 .{ }^{67}$ Only $\$ 25$ million was attributable to audit services; the rest was for consulting and non-audit services. Thus, the question raised is whether the desire to retain the non-audit revenues compromised Arthur Andersen's administration of the annual audit or caused it to turn a blind eye to obvious or easily discoverable wrongdoing.

The Act lists nine types of services that may no longer be performed by accounting firms such as bookkeeping and other maintenance of accounting records, financial information systems design, valuation services and fairness opinions, actuarial services, management functions including human resources, legal services and investment adviser services. ${ }^{68}$ Beyond this catalogue, the Board may prohibit the provision of other non-audit services. And, as has been seen, a company's audit committee must sign off in advance on the outside auditor's provision of all audit and still permitted non-audit services, such as tax services. ${ }^{69}$

\section{K. Lawyers' Duty of Intracorporate Whistle Blowing}

Perhaps lost in the mists of time are the SEC's efforts to obtain injunctive relief against two prestigious law firms (White \& Case of New York and Lord, Bissell \& Brook of Chicago) in SEC v. National Student Marketing Corp. ${ }^{70}$ The SEC contended that, when faced with suspicious accounting irregularities, lawyers should not have closed a merger transaction. Instead, they should have resigned and blown the whistle to the SEC. Judge Parker refused to grant the injunction the Commission requested. Many chalked National Student Marketing up to an overzealous manifestation of "post Watergate" morality among SEC commissioners and staff.

Later, the SEC retreated from Judge Parker's position, but in a Rule 2(e) disciplinary proceeding the Commission did announce a rule for "in-

66. See, e.g., Branson, supra note $3, \S 5.04$ (discussing SEC's regulations controlling conflicts of interest).

67. See id. (discussing SEC's regulations to prevent accounting conflicts of interest).

68. See Sarbanes-Oxley Act $\S 201$ (a) (to be codified as of Securities Exchange Act) $\S 10 \mathrm{~A}(\mathrm{~g})$.

69. For a further discussion of audit committee requirements, see supra notes 44-51 and accompanying text.

70. 457 F. Supp. 682 (D.D.C. 1978). 
ternal whistle blowing" for lawyers who practice securities law. In In re Carter, ${ }^{71}$ the Commission held that, upon discovery of material disclosure rule violations and the failure of a client to take corrective actions, "the lawyer must take further, more affirmative steps," such as "[a] direct approach to the board of directors or one or more individual directors or officers."72

Sarbanes-Oxley mandates internal whistle blowing by attorneys who practice before the SEC. The SEC is to prescribe "minimum standards of professional conduct for attorneys." 73 Those rules require attorneys "to report evidence of a material violation of securities law or breach of fiduciary duty or similar violation by the company or any agent thereof." 74 The attorney must first report the violation to the public company's chief legal counsel or CEO. If those officials do not take appropriate action, the attorney then must report the evidence of wrongdoing to the audit committee, to the independent directors or to the full board of directors.

The penalty for a failure to blow the whistle may be censure, suspension or revocation of the privilege of practicing before the SEC. The provision, which is the brain-child of North Carolina Senator Edwards, himself a successful attorney, also makes clear the SEC's authority to promulgate practice rules. The SEC is expressly given power to discipline a person found not to possess "the requisite qualification to represent others," to be "lacking in character or integrity, to have engaged in unethical or improper professional conduct" or to have willfully violated or aided and abetted a violation of the securities laws.

\section{Umbrella Whistle Blower Protection Provision}

One set of monitors we often pass over are rank-and-file middle managers and other employees. Two such managers at Enron blew the whistle, but to no avail. Jeffrey McMahon, Enron's treasurer, met with Jeffrey Skilling in March 2001 to raise his concerns about the SPEs and Andrew Fastow's related conflicts of interest. Skilling refused to acknowledge that any conflicts existed. He later testified, and maintained his facade of non-recognition, that the conflict of interest waivers Fastow later procured were approved in a meeting in which the lights went out, but discussion continued in the dark-while Skilling had ducked out of the room. ${ }^{75}$

The more famous Enron whistle blower was Sherron Watkins, a VicePresident for Corporate Development. The day after Jeffrey Skilling suddenly resigned as CEO, August 15, 2002, she wrote a memorandum to Kenneth Lay that began: "I am incredibly nervous that we will implode in

71. [1981 Transfer Binder] Fed. Sec. L. Rep. (CCH) II 82,847 (Feb. 28, 1981).

72. Id.

73. See Sarbanes-Oxley Act $§ 307$.

74. Id.

75. See Fusaro \& Miller, supra note 26, at 140-41 (detailing Fastow's dealings regarding relevant conflict of interest waivers). 
a wave of accounting scandals." Watkins singled out the Raptor SPE transactions Fastow had engineered, but also voiced wider concerns. Lay met with her three times and commissioned a law firm to investigate her allegations. The law firm (Vinson \& Elkins, Enron's regular outside counsel) spent approximately forty hours on the matter, reporting back to Lay that Watkins's fears were unfounded. ${ }^{76}$ Shortly after this episode, Enron shifted Watkins to Human Resources.

Presently, a criminal statute makes unlawful efforts by companies that "discharge, demote, suspend, threaten, harass or in any other manner discriminate" against an employee who provides information to, or otherwise assists, a federal regulatory or law enforcement agency, a member of Congress or "a person with supervisory authority" over the employee. ${ }^{77}$ If the employee complains about conduct he or she "reasonably believes" to constitute a violation of the securities laws or federal laws prohibiting fraud, he or she is protected. ${ }^{78}$

Another provision creates an express civil cause of action for whistle blowers who have been fired or demoted. These persons may seek reinstatement, compensatory damages including back pay with interest, litigation costs and attorneys' fees. ${ }^{79}$

There are other provisions of Sarbanes-Oxley, such as a new, longer limitations period for securities fraud actions, real time reporting on SEC Form $8 \mathrm{~K}$ and authority for the SEC to promulgate rules requiring independence and objectivity by securities analysts. A problem with SarbanesOxley is that it goes off in so many different directions that it is difficult to get one's arms around it or to explain all of what it does in any coherent way. That said and done, it is time to make an overall assessment of the legislation.

\section{An Overall Assessment of Sarbanes-Oxley}

\section{A. Background}

The Bush administration and Congress's approach is heavily regulatory, if not punitive: $\mathrm{CEO} / \mathrm{CFO}$ certification of financial statements with severe penalties for non-compliance, ${ }^{80}$ multiple reports on internal accounting controls, real time disclosure to the SEC, two day electronic reporting of executives' stock transactions, beefed up audit committees, codes of ethics for senior financial officers and much more.

76. See id. at 125-27 (discussing Enron's evaluation of accounting fears voiced by Watkins).

77. See Sarbanes-Oxley Act $\S 806$ (to be codified as 18 U.S.C. $\$ 1514 A$ ).

78. See id.

79. See Sarbanes-Oxley Act $\$ 806(\mathrm{~b})$.

80. The penalties are up to ten years in prison and $\$ 1$ million fine for "knowing" violations. The penalties escalate to up to twenty years and $\$ 5$ million for "willful" violations. 
Overall, though, we should remember that the current United States governance regime has worked well, presiding over a decade of economic growth unrivaled in our history. We should seek out what is good about that regime in order to enhance it.

Regulatory approaches of the sort adopted have many faults. They deter the informed risk taking we want corporate managers to take. They add to the already considerable amount of regulation in existence. Regulation begins to resemble sumptuary laws. Law is trivialized. More regulation gives real wrongdoers and clever lawyers a stationary target. Most of all, punitive and regulatory approaches often result only in "closing the barn door after the horse is gone." In other words, they are the stick rather than the carrot.

Traditionally, our approach to governance has relied on external monitors who were proactive and objective, free of conflicts of interest. These monitors, some of which rise to the level of gatekeepers in my scheme, have substituted for owners (shareholders) who have become geographically dispersed and atomized in their holdings. Due to what may be called collective action problems (identifying who fellow owners are, communication costs, the SEC's proxy regulation scheme), owners found it difficult to reassert themselves. Further, they could not efficiently monitor management even if they wanted to, which most often they did not.

Proactive monitors of management substitute for dispersed owners and nip dubious schemes in the bud. Capable monitors close the barn door while the horse remains in the stall.

Two such groups of monitors have failed us badly in the recent era, namely, high profile corporate lawyers and "Big Five" firm accountants. Law firms used to have (and some still maintain) a senior lawyer or two who were the "deal gurus," ethical watchdogs. Novel transactions and legal "stretches" had to be run by the deal guru who might refuse his imprimatur, stating reasons, or just relying on a "smell test." "We won't sign off on that" meant a trip back to the drawing boards. Apparently, no senior partner at either Vinson \& Elkins or Kirkland \& Ellis filled that role as progressively more bizarre transactions were structured for Enron.

In the area of accounting, in the 1970s, the SEC took steps to enhance auditor independence. A change of auditors was made a reportable event for purposes of SEC Form 8K. Firms who had disagreements and fired auditors had to report that situation publicly and almost instantaneously. The SEC brought several high profile court cases against corporations who manipulated or disregarded auditors' advice or commands.

Today, more often than not, profit means more than principle. Law and accounting have become businesses rather than professions. From the corporate standpoint, legal and accounting services have become commodities. If corporations can discover more compliant, or cheaper service providers, corporations might migrate to them. Corporations spread their 
legal business around so no one law firm, or law firm partner, has an overview of the corporation's activities.

Over the last twenty years, however, a third monitor has gained strength, while the two groups of traditional monitors (accountants and lawyers) have become weaker. The third monitor is the independent director or, more precisely, a board comprised of a super majority of truly independent directors. Directors who have stature, integrity and true independence predominate on most corporate boards. Gone are outside directors who have financial ties to the corporation or its managers. Consequently, lawyers, investment bankers, commercial bankers and other professional advisers seldom serve on boards anymore.

Proactive independent directors forcibly removed underperforming or misguided CEOs at nine percent of the Fortune 500 in the first half of the 1990s. At some corporations such as Apple Computer and General Motors, directors did so more than once.

\section{B. Fine Tuning the Corporate Board}

We ought to take steps to enhance the independence of boards of directors and otherwise polish the one bright light on the corporate governance scene, as follows.

\section{Real Time Reporting of Director Removal or Non Renomination}

We should make the forced resignation, or failure to re-nominate an incumbent independent director, a reporting event both for purposes of SEC Form $8 \mathrm{~K}$ and the annual proxy statement, as the SEC has done in part. The corporation should have to disclose the reasons for the resignation or failure to re-nominate. The removed director (Walter Hewlett, for instance) should be given an opportunity to respond.

\section{Mandate the Nominating Committee}

In its governance guidelines, the NASDAQ should require a nominating as well as an audit committee, as the NYSE recently has. NYSE and NASDAQ guidelines should require that independent directors including at least one female or director of color, should staff the committee. Guidelines should prohibit membership by the CEO (when Archer Daniels Midland (ADM) CEO H. Dwayne Andreas sat on the nominating committee, wags said that ADM also referred to the board, short for "All Dwayne's Men"). We have seen too many instances (American Express, Scott Paper, Sunbeam, Archer Daniels Midland, Morrison Knudsen, to name a few) in which a CEO has been able to remold or reshape a board, thus postponing a comeuppance for under performance or wrongdoing. 


\section{Strengthen Director Education}

Some countries, such as Malaysia, have instituted mandatory training and certification programs for independent directors. That goes too far. But independent director associations and institutes should be materially strengthened and given prominence. The Institute of Company Directors in Australia is worth emulating. A component of training might involve increasing the accounting and financial literacy of additional (but not necessarily all) directors so that literacy extends well beyond the audit committee membership. In other professions (law, medicine and accounting), continuing education is of central importance. Why not for independent directors of large corporations?

\section{Separate the Offices of CEO and Chairperson}

Most other countries with well developed "best governance practices" require a separation between the offices of $\mathrm{CEO}$ and Chairperson. In fact, the United States is a laughing stock in comparative corporate governance circles. Many wonder, "How can the board of independent directors effectively monitor a CEO who as Chairman controls the timing of, and the agenda for, meetings?" The lead director concept espoused by the New York Stock Exchange does not get the job done. ${ }^{81}$ It is time for the United States to bite the bullet on this one. We should meet the prevailing international standard.

\section{Come Down Hard on Trophy Directors}

Anne McLaughlin Korologos, a former Secretary of Labor, sits on eleven boards. Rozanne Ridgeway, a former Assistant Secretary of State, sits on eight. There should exist strong disincentives for board service on more than two, or, at most, three boards of large, publicly held companies. Directors who serve on six, eight or more boards simply are not capable of the monitoring required. They are there for window dressing, or because they are glad-handers or back-slappers.

\section{Board Lessons from Enron}

\section{The Obvious Lessons}

Enron is what I call a "roadmap" or "reverse roadmap" case. ${ }^{82}$ If, at every crucial juncture, a board of directors takes the track opposite the

81. The lead director is a second-best compromise reached when a powerful CEO refuses to vacate the office of board chair. See, e.g., Joann S. Lublin \& Bruce Orwall, To Buttress Governance, Disney Mulls Post of Presiding Director, WALL St. J., Dec. 2, 2002, at A3 (discussing Disney CEO Michael Eisner's unwillingness to vacate post of chairman).

82. See, e.g., Douglas M. Branson, Intracorporate Process and the Avoidance of Director Liability, 24 WAKE FOREST L. REv. 97, 102 (1989) (explaining "roadmap" and "reverse roadmap" cases, which provide process models for corporate management in contexts such as maintaining duty of care). 
one the Enron board took, that later board will sail through, if not with flying colors, then at least away from the shoal water. So considered, Enron's teachings are obvious.

For example, Enron directors were often told that Enron was engaged in "high risk" accounting practices-practices that "push the limits." 83 The obvious teaching for later boards: scrutinize closely novel accounting practices and tread warily with any such practices that "push the limits."

Enron had an audit committee of six members, chaired by the exdean of Stanford's Graduate School of Business, Dr. Robert K. Jaedicke, whose specialty is accounting. The audit committee should have been the first line of defense against the accounting irregularities and off-books shenanigans that occurred. The committee failed, quite badly. Thus, once again, post-Enron the teachings are obvious: strengthen requirements for audit committees by requiring the audit committee chair to possess financial management or accounting expertise, and by requiring a written audit committee charter that obligates the committee to oversee the company's financial statements and accounting practices and to hire and fire the outside auditor. ${ }^{84}$

In 1999 and again in 2000, Andrew Fastow requested that the board grant waivers of conflict of interest prohibition in the Enron Code of Conduct. Fastow made the request to be able to act as the managing partner of the LJM1 and LJM2 partnerships. Fastow then proceeded to take advantage of Enron in many Enron-LJM transactions, reaping $\$ 45$ million in compensation for himself. The teaching: have a company-wide code of conduct, police its enforcement and grant waivers sparingly, if at all.

All of the corporate governance gurus, self proclaimed or otherwise, have been reiterating and elaborating on these obvious teachings of Enron. The repetition and re-examination are certainly beneficial. But the question the remainder of this Article asks is what are the less obvious teachings? Are there bits of advice to be gleaned from Enron that have not been splashed in the pages of the law reviews, business journals, Wall Street Journal or New York Times?

\section{Enron's Subtle Teachings}

a. The Independent Directors, Either as a Committee of the Whole, or While Serving on Audit, Finance, Nomination or Other Committees, Must Exclude Senior Managers from Part or All of Their Sessions

Enron's board of sixteen members was a hard-working board. Customarily, they had five regular meetings per year, each of which began with a dinner followed by two full days of meetings thereafter. ${ }^{85}$ In addi-

83. See The Role of the BoArd of Directors in Enron's Collapse, S. Rep. No. 107-70, at 12, 14 (2002).

84. See id. at 4 (setting forth final committee recommendations).

85. See id. at 9 (detailing Enron board's traditional schedule). 
tion, the board had one or two meetings a year away from Houston, often at a foreign locale in which Enron had a facility. ${ }^{86}$

On the first day of meetings, most of the Enron board's five committees (executive, finance, audit and compliance, compensation and nominating) would meet. ${ }^{87}$ No committee met without the presence of former CEO Kenneth Lay, CEO Jeffrey Skilling or both, as well as other senior managers. ${ }^{88}$ The independent directors never met in executive session, and there was not a designated "lead" or "presiding" director to convene such meetings. ${ }^{89}$

Independent directors have to assure themselves of opportunities for acting independently. Otherwise, their presence on the board may become an empty gesture. A good practice might be for the independent directors to meet at least once per year. A further practice might be to exclude senior managers from part or all of committee meetings.

\section{b. Ensure Auditor "Face Time" with the Audit Committee}

Arthur Andersen regularly sent three partners to Enron board meetings. Those partners, however, never met with the audit committee without the senior managers being present. Skilling, Lay and others always were in the room with the auditors and audit committee. ${ }^{90}$ How can the audit committee and auditors make a frank assessment of the abilities and performance of senior accounting and financial personnel, a central audit committee function, if the captains of the management team are hovering over the deliberations? Like the previously discussed teaching, this is a simple point, but it may point to the precise juncture at which Enron began to spin out of control.

c. The Board Should Conduct, or Oversee the Conduct of, “ 360

Degree" Reviews of Senior Executive Officers

One view of Enron may be that nothing untoward occurred until the fourth story recounted above, when the finance unit began to make a mockery of the use of off-books special purpose entities. The corollary is that, as with Scott Sullivan at WorldCom or the Rigas family at Adelphia Communications, the cause of the eventual failure of the firm was the wrongdoing of one or two individuals, rather than some sort of systemic governance failure.

86. See, e.g., id. at 15-16 (discussing Enron operations, audit committee meetings and board meetings in England and India).

87. See id. at 9 (describing Enron board committees).

88. See id. at 10 (noting attendance at various committee meetings).

89. See id. (identifying structure of Enron board committee meetings).

90. See id. at 10,57 (noting presence of Lay, Skilling and others at all Audit Committee meetings and that " $[t]$ he audit committee had very limited contact with Andersen, essentially communicating with Andersen personnel only at Board meetings"). 
In the human resources world, the " 360 degree" annual review is becoming common. Superiors, peers and subordinates, as well as others (customers, outside auditors, lawyers) review a manager's performance. Some corporate boards now undertake "360 degree" reviews of the CEO and of the board chair. Still other boards cause " 360 degree" reviews to be conducted of all senior managers.

Had the Enron board done so, an argument may be made that Fastow and the finance unit he headed could never have wandered as far afield as they did. If not as a matter of course, the conduct of a performance review could have been triggered by Fastow's first request for a code of conduct waiver, in early to mid-1999. ${ }^{91}$ As it was, there were no meaningful reviews of Fastow or of his department. Even CEO Jeffrey Skilling testified that he "did not, as a matter of course, review [the LJM] transactions for fairness or sign the relevant documents." 92 The first serious questioning did not occur until October 2001, a month before Enron entered bankruptcy.

At that time, board and compensation committee member Dr. Charles LeMaistre was detailed by his committee to question Fastow. ${ }^{93} \mathrm{Dr}$. LeMaistre's handwritten notes "indicate[d] that Mr. Fastow admitted receiving LJM compensation totaling $\$ 45$ million, $\$ 23$ million from LJM1 and $\$ 22$ million from LJM2." 94 In a handwritten note in the margin, Dr. LeMaistre referred to this finding as "incredible."

\section{d. Provide for Effective Networking and Coordination Among Board Committees and Between a Committee and the Full Board}

Much of the modern board's work is done through committees, and post Sarbanes-Oxley, perhaps too much so. Whether the latter is true is a question that might be examined in the future.

What is clear from the Enron debacle is that the committees failed adequately to communicate with one another. Thus, for example, in October 1999, the finance committee conducted a "vigorous discussion" regarding the LJM partnerships and the potential for abuse. ${ }^{96}$ They intended to put in place a set of controls to ensure that Enron received fair deals from the LJM transactions with various special purpose entities. ${ }^{97}$

91. See id. at 24.

92. $I d$. at 29.

93. See id. at 33 .

94. Id. at 34 .

95. See id. (describing LeMaistre's handwritten notes from his conversation with Fastow).

96. See id. at 25-26 (detailing board meeting to ratify second code of conduct waiver that would allow Fastow "to set up and manage LJM2, hold an ownership interest in the fund, locate additional investors and financing, and receive compensation for his efforts").

97. See id. (discussing purpose of board meeting). 
The finance committee, however, depended on the audit committee to supplement and implement the controls, but, evidently, did not coordinate that process with the audit committee. ${ }^{98}$ Meaningful review of the LJM partnership transactions thus fell between the cracks that existed between the two board committees. The handoff to the audit committee was incomplete. The effort was piecemeal and haphazard.

The answer may be a "committee on committees" structure. The full board may serve that function, but in this author's experience at least, the portion of a board meeting devoted to committee reports generally is the portion that garners the least attention from fellow directors. They are opening mail, scanning their board packet or are otherwise distracted, eager to get through committee reports and on to the main agenda. They do not ask probing questions, let alone inquire into how well committees are networking with one another. Perhaps, as an adjunct to meetings of the full board, and as a "committee on committees," the committee chairs should hold a short meeting to discuss overlaps and joint efforts by committees.

e. Limit Cash and Stock Compensation for Directors to Near the Mean for Similar Public Companies and Prohibit Consultantships for Directors

Enron paid Lord John Wakeham, a chartered accountant, $\$ 72,000$ per year for consulting services in accounting. ${ }^{99}$ Board member John Urquhart and his Connecticut based consulting firm received $\$ 493,914$ in 2000. ${ }^{100}$ Board member Charls Walker, a tax lobbyist, received $\$ 70,000$, paid to firms he controlled. ${ }^{101}$ A company on whose board director îerbert Winokur also served, the National Tank Company, sold $\$ 1,035,000$, $\$ 643,793, \$ 535,682$ and $\$ 370,294$ of equipment to Enron in the years $1997-2000 .{ }^{102}$

Enron donated $\$ 50,000$ to George Mason University and its Mercatus Center headed by board member Dr. Wendy Gramm. ${ }^{103}$ Over five years, Enron, and Chairman Ken Lay, contributed over $\$ 600,000$ to the Andersen Cancer Center, over which two Enron board members, Dr. Charles LeMaistre and Dr. John Mendelson, had at various time presided as president. $^{104}$

98. See id. at 30 ("The Audit Committee was charged by the Board with performing an annual review of the LJM transactions.").

99. See id. at 51 (discussing Enron's payments to board member John Wakeham).

100. See id. (discussing Enron's payments to board member John Urquhart). Walker).

101. See id. at 52 (discussing Enron's payments to board member Charls

102. See id. at 51-52.

103. See id. at 52 (discussing Enron's ties to outside board members).

104. See id. 
In the Senate hearings, Professor Charles Elson of the University of Delaware testified unequivocally that directors should have "no financial connection to the company whatsoever," other than their board compensation. ${ }^{105}$ Elaborating, he stated that "[i]f a director's role is as a consultant, hire the director as a consultant. If the director's role is to be a director, hire him as a director. You cannot blend the two." ${ }^{106}$ Retired Sunoco board chair and CEO, Robert Campbell, agreed with Professor Elson: "consulting arrangements with directors are absolutely incorrect, absolutely wrong." 107

The courts have not agreed. For example, in Katz $v$. Cheoron Corp., ${ }^{108}$ the Court found that, as a matter of law, receipt by a director's investment banking firm of a $\$ 229,000$ fee did compromise the director's status as an independent director. ${ }^{109}$ Nonetheless, best practices support Professor Elson's and Mr. Campbell's views, rather than the findings of judges in legal matters.

In addition to Enron's consultantships, charitable donations and business dealings with firms they controlled, Enron directors also benefited from generous direct compensation: "Enron board members were compensated with cash, restricted stock, phantom stock units and stock options. The total cash and equity compensation of Enron board members in 2000 was valued by Enron at about $\$ 350,000$ or more than twice the national average for board compensation at U.S. publicly traded corporations." 10 But members of the Enron board were persons of high reputation and integrity. They would neither compromise their integrity nor jeopardize their reputations for the sake of high board compensation. Similarly, it can be said of all, or most, Enron directors, neither consulting arrangements nor charitable gifts to favored charities nor any other financial inducement would cause them to do what they believed to be morally wrong or even bad business practice.

Instead, the corrupting influence of inordinate board compensation is more subtle. High compensation leads more to group think than individual corrupt acts. It leads to a culture of "winning," a culture of success that may or may not be justified by the underlying economic reality of what is occurring within the company. It leads to a culture that has high on its agenda preservation of the good times, for board members as well as executives of the company.

105. See id. at 53.

106. Id. at 52-53.

107. Id.

108. 27 Cal. Rptr. 2d 681 (Cal. Ct. App. 1994).

109. See id. at 689-90 (analyzing whether Samuel Armacost, outside director of company at issue, was "in a position to base his decision on the merits of the issue rather than being governed by extraneous considerations or influences"). See generally BRANSON, supra note $3, \$ \S 7.08-7.10$.

110. S. ReP. No. 107-70, at 11. Average total board compensation at the top two hundred U.S. public corporations in 2000 was $\$ 138,747$. See id. at $11 \mathrm{n} .9$ (providing background statistics). 
In the first years of Enron's innovation and climb to the top, the culture was justified by the underlying reality. In the last few years, the opposite occurred. High board compensation and the winner's culture thereby engendered prevented the board from seeing early signs that the underlying reality was crumbling. The board of directors, its committees and perhaps even some of the senior executives went blithely on, lulled into a false sense of security by their high compensation, consulting and similar arrangements and rising share price.

\section{Conclusion: Creative Destruction of a Different Kind}

When I visit law school classmates, I find that after twenty-five years of law practice, many have become wealthy. They have not achieved wealth directly, through the practice of law. They have achieved wealth indirectly-by investing in clients' businesses or by going into partnerships with clients. I remonstrate with them. "What about the conflicts of interest?" "What about the loss of objectivity?" "What about the possibility of being sued?"

They reply, "We've got the 'good deal exemption' on this one." Others of them remind me that "a rising tide floats all boats." If a client's business is a "sure thing," the increasing value of everyone's investment covers over any conflicts of interest or loss of objectivity. Rising tides not only float all boats, they cover up mistakes, intuition gone awry and even some forms of intentional wrongdoing.

Enron embodied that "ever rising tide" culture, what Professor William Bratton refers to as the "culture of winning." 111 So too did WorldCom, Global Crossing, Tyco and ImClone. Enron's most important contribution to our political economy may then be neither SarbanesOxley, which may not achieve significant "real" reform, nor any other discrete reform that this or any other article may discuss. Enron's contribution instead has been to dampen down or kill off that culture and the moral hazards it presents. Enron's most important teaching is its least obvious one.

111. See, e.g., William W. Bratton, Enron and the Dark Side of Shareholder Value, 76 Tul. L. Rev. 1275, 1360 (2002) ("It all came to a head with Enron, where pressure to maximize and a culture of winning combined to draw a huge firm into riskprone decision making."). 
Villanova Law Review, Vol. 48, Iss. 4 [2003], Art. 1

1022

Vill.anova Law Review

[Vol. 48: p. 989 